\title{
IMPLEMENTASI ALGORITMA GENERATE AND TEST PADA PENCARIAN RUTE TERPENDEK
}

\author{
Selvy Welianto ${ }^{(1)}$ \\ selvywelianto@yahoo.com
}

\author{
R. Gunawan Santosa ${ }^{(2)}$ \\ gunawan@ukdw.ac.id
}

\author{
Antonius Rachmat C. ${ }^{(3)}$ \\ anton@ukdw.ac.id
}

\begin{abstract}
Abstraksi
Masalah pencarian merupakan masalah yang umum diterapkan pada sistem berdasarkan Kecerdasan Buatan. Salah satu metode pencarian heuristik dalam terminology Kecerdasan Buatan yang cukup dikenal adalah Generate and Test. Travelling Salesman Problem (TSP) atau dipahami sebagai pencarian jalur terpendek sering diimplementasikan ke dalam dunia nyata. Tujuan penelitian ini adalah mengimplementasikan konsep pencarian heuristik dengan algoritma Generate and Test pada pencarian rute terpendek dengan studi kasus bus Trans Jogja. Parameter yang digunakan adalah jarak atau waktu. Dari hasil penelitian ini didapatkan sebuah sistem yang mampu menemukan rute terpendek, rute alternatif (jika ada), saran trayek yang digunakan beserta analisis perhitungan setiap rute yang ditemukan.
\end{abstract}

Kata kunci : pencarian, algoritma Generate and Test, bus Trans Jogja

\section{Pendahuluan}

Pada umumnya, banyak masyarakat Yogyakarta terutama pendatang baru tidak memiliki alat transportasi pribadi seperti sepeda motor maupun mobil. Oleh karena itu, alat transportasi umum menjadi solusi untuk mencari tempat makan. Salah satu alat transportasi umum adalah bus

\footnotetext{
${ }^{1}$ Teknik Informatika, Fakultas Teknologi Informasi,Universitas Kristen Duta Wacana

${ }^{2}$ Teknik Informatika, Fakultas Teknologi Informasi Univeristas Kristen Duta Wacana

${ }^{3}$ Teknik Informatika, Fakultas Teknologi Informasi,Universitas Kristen Duta Wacana
} 
Trans Jogja. Akan tetapi tidak banyak masyarakat yang menggunakan bus ini dikarenakan tidak mengetahui rute bus, lokasi halte, serta jalan yang dilalui pada setiap rutenya.

\section{Landasan Teori}

Beberapa dasar teori yang menjadi landasan penulisan, yaitu search, heuristik, teori graf, dan algoritma Generate and Test, dan bus Trans Jogja.

\subsection{Search}

Menurut Luger (2005), search adalah sebuah teknik menyelesaikan masalah (problem solving) yang mengembangkan sebuah ruang permasalahan secara sistematik dalam sebuah proses. Terdapat 4 kriteria untuk menentukan performa sebuah metode pencarian, yaitu Completeness, Time Complexity, Space Complexity, dan Optimality. Completeness adalah apakah metode tersebut menjamin ditemukannya solusi jika solusi tersebut ada. Time Complexity adalah lama waktu yang dibutuhkan untuk menemukan solusi tersebut. Space Complexity adalah jumlah memory yang diperlukan dan yang dimaksud Optimality adalah apakah metode tersebut menjamin menemukan solusi yang terbaik jika terdapat beberapa solusi yang lain.

Metode pencarian dibagi menjadi dua strategi, yaitu uninformed search dan informed search. Uninformed search merupakan suatu strategi pencarian tanpa ada informasi mengenai cost (bobot) atau informasi tertentu sedangkan Informed search merupakan suatu strategi pencarian yang membutuhkan informasi mengenai cost (bobot) atau informasi tertentu.

\subsection{Heuristik}

Heuristik berfungsi untuk meningkatkan efisiensi dari sebuah proses pencarian. Tidak semua teknik heuristik memenuhi empat kriteria performa suatu metode pencarian. Fungsi heuristik digunakan untuk menghitung path cost dari suatu node awal menuju node tujuan. Fungsi heuristik yang digunakan dalam penelitian ini adalah Straight-line distance atau jarak secara garis lurus. Jarak yang digunakan dalam penelitian ini adalah jarak dan waktu sebenarnya yang diperoleh penulis dari Dinas Perhubungan Komunikasi dan Informatika.

\subsection{Teori Graf}

Beberapa terminology graf yang dibahas adalah verteks, edge, graf tidak berarah, graf berarah, graf berbobot, dan path (lintasan). 
Verteks merupakan titik atau node yang menunjukkan tempat yang dijadikan sebagai goal atau tujuan, start atau awal, atau tempat yang akan dilalui dalam suatu perjalanan. Edge merupakan garis penghubung antar verteks. Graf tidak berarah (undirected graf) merupakan graf yang tidak memiliki arah dan anak panah sehingga dapat dilalui oleh dua arah yang berlawanan.

Graf berarah (directed graf) merupakan graf yang memiliki arah dan biasanya ditunjukkan dengan sebuah anak panah dengan salah satu ujungnya disebut tail (ekor) dan head (kepala). Graf berarah tidak dapat dilewati oleh dua arah yang berbeda. Graf berbobot merupakan graf yang memiliki bobot atau nilai di setiap edge-nya dan dapat berupa graf berarah maupun graf yang tidak berarah. Path (lintasan) merupakan suatu lintasan yang melalui verteks dan edge dimana verteks tidak boleh dilewati lebih dari satu kali.

\subsection{Algoritma Generate and Test}

Algoritma Generate and Test merupakan algoritma paling sederhana dalam teknik pencarian heuristik. Dalam Generate and Test, terdapat dua prosedur penting yaitu generate (membangkitkan) yaitu membangkitkan semua solusi yang mungkin dan test (pengetesan) yaitu menguji solusi yang dibangkitkan tersebut. Algoritma Generate and Test menggabungkan algoritma DFS dengan pelacakan mundur (backtracking), yaitu bergerak ke belakang menuju state awal.

Algoritma Generate and Test adalah sebagai berikut :

1. Bangkitkan sebuah solusi yang mungkin

2. Menguji tiap-tiap node yang merupakan solusi dengan cara membandingkan node tersebut dengan node akhir dari suatu lintasan yang dipilih dengan kumpulan tujuan yang diharapkan.

3. Jika solusi telah ditemukan, maka keluar dari sistem. Jika belum menemukan solusi, maka kembali ke langkah 1.

\subsection{Bus Trans Jogja}

Bus Trans Jogja resmi beroperasi pada akhir 2007 dengan jam operasi antara pukul 05.30 21.30 WIB dan berhenti di halte-halte khusus yang telah disediakan. Sekarang ini, total jumlah halte yang ada dan tersebar di DIY adalah 108 halte ditambah dengan 4 terminal yang menjadi tempat singgah dan transit bus Trans Jogja sehingga total seluruhnya adalah 112 tempat yang dilalui oleh bus Trans Jogja. Trans Jogja memiliki 8 trayek yaitu 1A, 1B, 2A, 2B, 3A, 3B, 4A, dan 4B. 


\section{Hasil dan Pembahasan}

Berikut ini akan disajikan gambar implementasi sistem yang telah dibuat oleh penulis. Gambar 1 menunjukkan implementasi tampilan awal Form Utama. Gambar 2 menunjukkan implementasi tampilan Form Utama setelah dilakukan pencarian. Gambar 3 menunjukkan implementasi tampilan Form Analisis. Form Analisis berfungsi untuk menunjukkan halte yang dilewati beserta trayek yang digunakan, perhitungan jarak atau waktu, total perpindahan trayek, serta daftar tempat makan sesuai dengan tujuan.

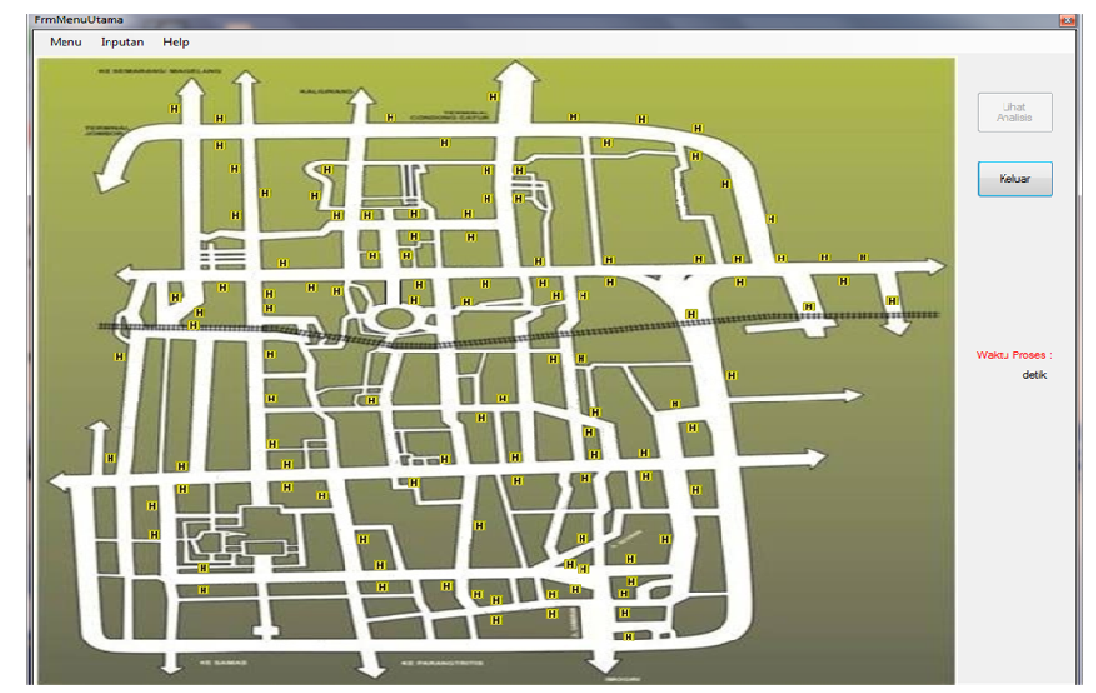

Gambar 1 Tampilan Awal Form Utama

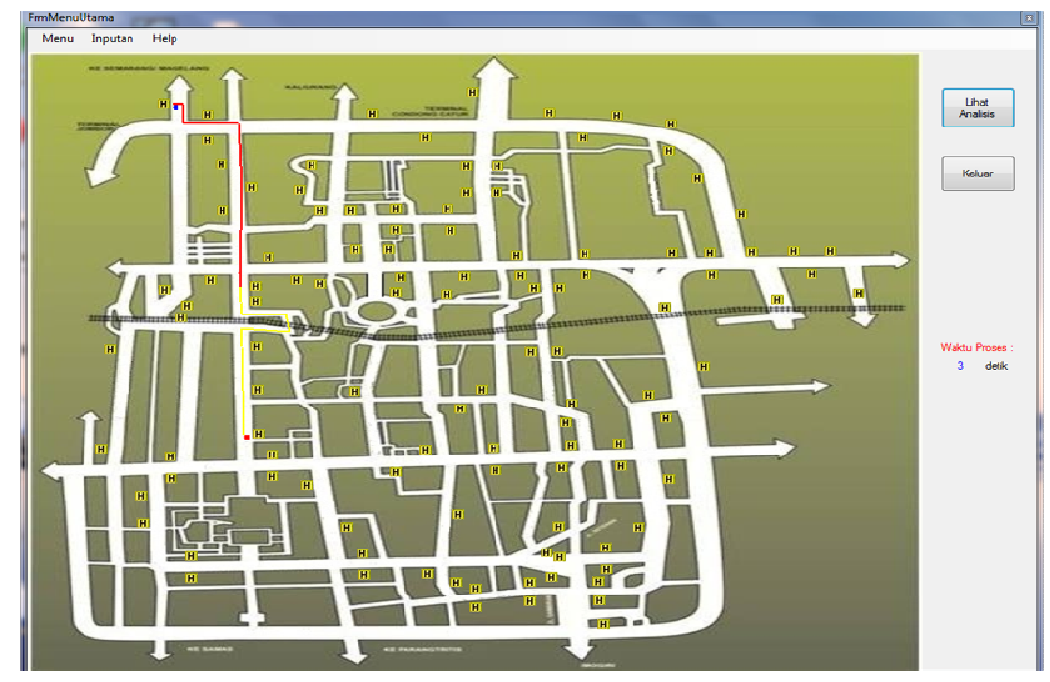

Gambar 2 Tampilan Form Utama Setelah Pencarian 


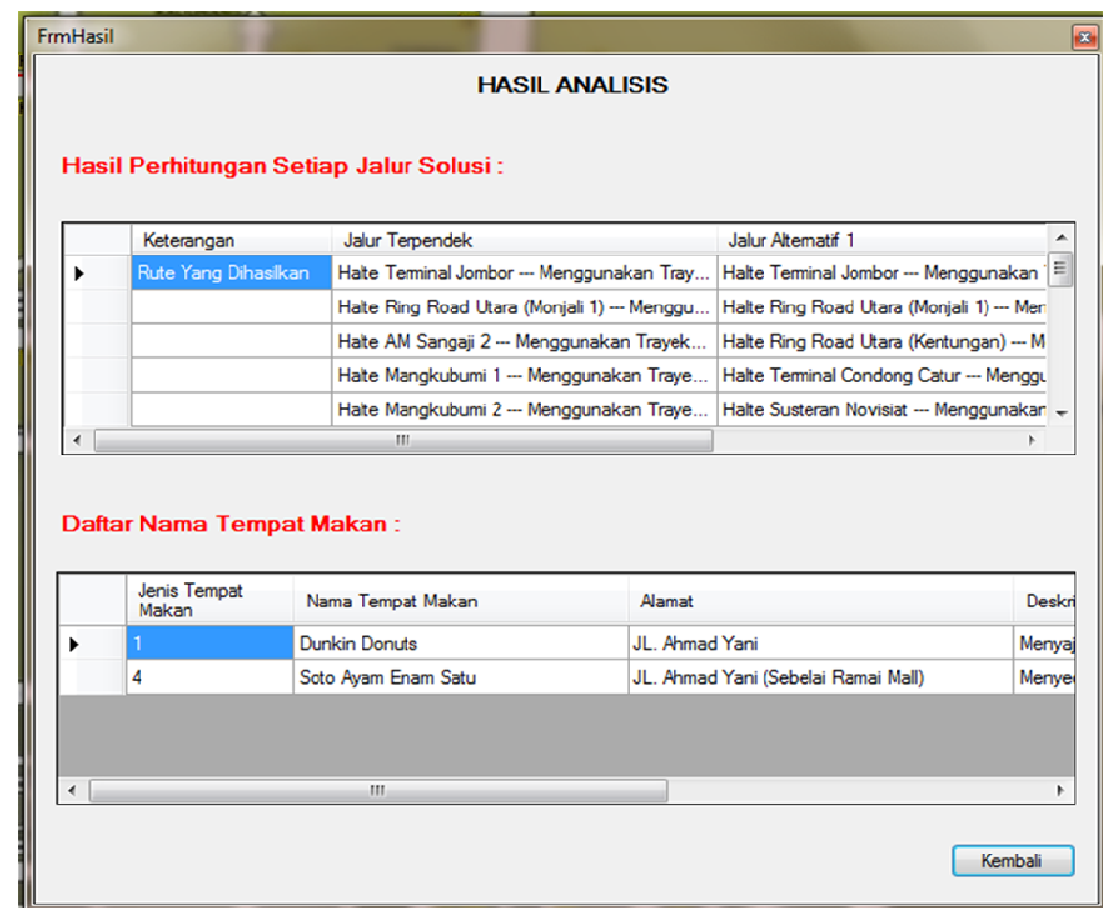

Gambar 3 Tampilan Form Analisis

Berikut ini adalah contoh penyelesaian kasus algoritma Generate and Test dengan mengadaptasi situasi dan kondisi bus Trans Jogja. Gambar 4 dibawah ini menggambarkan kasus yang akan diselesaikan.

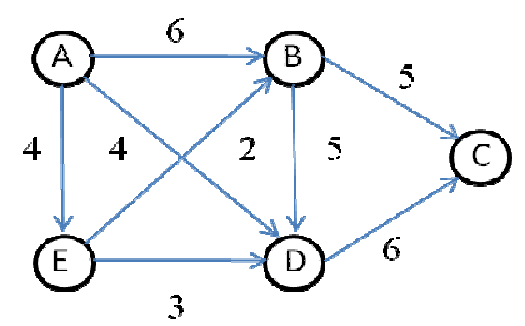

Gambar 4 Contoh Kasus

Pencarian dilakukan dari titik A menuju titik C dengan daftar trayek :

- 1 A melewati halte: A, D, dan C

- 2A melewati halte : A, E, D, dan C

- $1 \mathrm{~B}$ melewati halte : $\mathrm{B}$ dan D

- $\quad$ B melewati halte : A dan B

- $\quad 3$ A melewati halte : $B, C$ dan $\mathrm{E}$

Waktu jeda $1 \mathrm{~A}=5$ menit, $1 \mathrm{~B}=5$ menit, $2 \mathrm{~A}=7$ menit, $2 \mathrm{~B}=10$ menit, dan $3 \mathrm{~A}=7$ menit. 
Daftar waktu yang dibutuhkan adalah :

\begin{tabular}{|l|l|}
\hline $\mathrm{A}-\mathrm{B}=8$ menit & $\mathrm{B}-\mathrm{D}=7$ menit \\
\hline $\mathrm{A}-\mathrm{D}=5$ menit & $\mathrm{D}-\mathrm{C}=8$ menit \\
\hline $\mathrm{A}-\mathrm{E}=5$ menit & $\mathrm{E}-\mathrm{B}=3$ menit \\
\hline $\mathrm{B}-\mathrm{C}=7$ menit & $\mathrm{E}-\mathrm{D}=5$ menit \\
\hline
\end{tabular}

Berikut ini adalah langkah-langkah penyelesaian kasus di atas adalah :

1. Menjabarkan satu per satu kemungkinan yang ada. Gambar 5 menggambarkan proses penjabaran satu per satu kemungkinan yang ada.

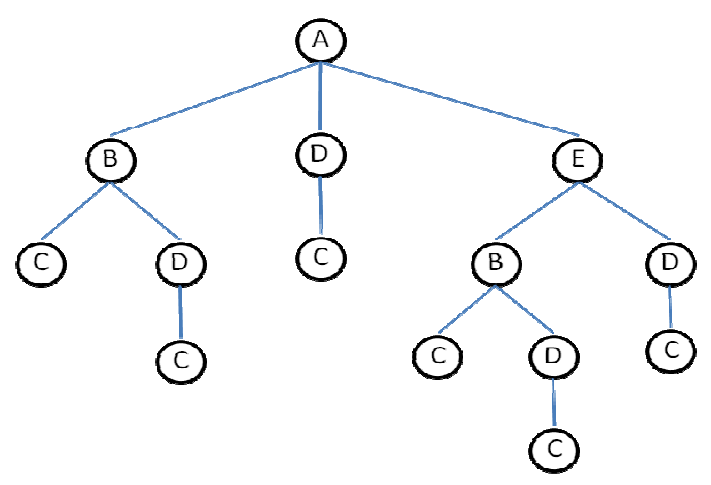

Gambar 5. Pohon Penyelesaian

2. Membuat daftar tabel beserta perhitungan jarak dan waktu untuk setiap jalur yang telah dilewati.

Tabel 1 Tabel Alur Pencarian Jarak

\begin{tabular}{|c|c|c|c|c|}
\hline & $\begin{array}{c}\text { Rute } \\
\text { yang } \\
\text { mungkin }\end{array}$ & $\begin{array}{c}\text { Pan } \\
\text { jang } \\
\text { Rute }\end{array}$ & $\begin{array}{c}\text { Rute } \\
\text { yang } \\
\text { Dipilih }\end{array}$ & $\begin{array}{c}\text { Panjang } \\
\text { Rute } \\
\text { yang } \\
\text { Dipilih }\end{array}$ \\
\hline 1 & ABC & 11 & ABC & 11 \\
\hline 2 & ABDC & 17 & ABC & 11 \\
\hline 3 & ADC & 10 & ADC & 10 \\
\hline 4 & AEBC & 11 & ADC & 10 \\
\hline 5 & AEBDC & 17 & ADC & 10 \\
\hline 6 & AEDC & 13 & ADC & 10 \\
\hline
\end{tabular}


Tabel 2 Alur Pencarian Waktu

\begin{tabular}{|c|c|c|c|c|}
\hline & $\begin{array}{c}\text { Rute } \\
\text { yang } \\
\text { mungkin }\end{array}$ & $\begin{array}{c}\text { Total } \\
\text { Waktu }\end{array}$ & $\begin{array}{c}\text { Rute } \\
\text { yang } \\
\text { Dipilih }\end{array}$ & $\begin{array}{c}\text { Waktu } \\
\text { yang } \\
\text { Dipilih } \\
\text { (menit) }\end{array}$ \\
\hline 1 & ABC & 15 & ABC & 15 \\
\hline 2 & ABDC & 23 & ABC & 15 \\
\hline 3 & ADC & 13 & ADC & 13 \\
\hline 4 & AEBC & 15 & ADC & 13 \\
\hline 5 & AEBDC & 23 & ADC & 13 \\
\hline 6 & AEDC & 18 & ADC & 13 \\
\hline
\end{tabular}

3. Dari Tabel 1 ditemukan rute terpendek berdasarkan jarak adalah $\mathrm{A}-\mathrm{D}-\mathrm{C}$ dengan total jarak $10 \mathrm{~km}$. Rute alternatif 1 adalah A - B - C dengan total jarak $11 \mathrm{~km}$. Rute alternatif 2 adalah A $-\mathrm{E}-\mathrm{B}-\mathrm{C}$ dengan total jarak $11 \mathrm{~km}$.

4. Dari Tabel 2 ditemukan rute terpendek berdasarkan waktu adalah $\mathrm{A}-\mathrm{D}-\mathrm{C}$ dengan total waktu 13 menit. Rute alternatif 1 adalah $\mathrm{A}-\mathrm{B}-\mathrm{C}$ dengan total waktu 15 menit. Rute alternatif 2 adalah $\mathrm{A}-\mathrm{E}-\mathrm{B}-\mathrm{C}$ dengan total waktu 15 menit.

5. Setelah melakukan perhitungan jarak dan waktu, langkah selanjutnya adalah menentukan trayek bus yang digunakan pada masing-masing rute. Tabel 3 menunjukkan penentuan trayek pada masing - masing rute. 
Tabel 3 Penentuan Trayek

\begin{tabular}{|c|c|c|c|c|}
\hline Rute & $\begin{array}{c}\text { Trayek } \\
\text { yang lewat }\end{array}$ & $\begin{array}{c}\text { Perhitungan } \\
\text { Jeda }\end{array}$ & $\begin{array}{c}\text { Total } \\
\text { Waktu }\end{array}$ & $\begin{array}{c}\text { Total } \\
\text { Pindah }\end{array}$ \\
\hline ADC & 1A & 0 & $13+0=$ & 10 \\
& & $10+7=17$ & $15+17$ & 1 \\
ABC & 2B, 3A & & 32 & \\
& & & $15+24$ & 3 \\
\hline AEBC & 2A, 3A, 1B, 1A & $5+7+7$ & $=39$ & \\
& & $+5=24$ & & \\
& & &
\end{tabular}

Berdasarkan analisis perhitungan yang dilakukan maka rute terpendek berdasarkan jarak adalah A - D - C dengan total jarak tempuh $10 \mathrm{~km}$ tanpa perpindahan.

Berdasarkan analisis perhitungan yang dilakukan maka rute terpendek berdasarkan waktu adalah $\mathrm{A}-\mathrm{D}-\mathrm{C}$ dengan total waktu tempuh 13 menit tanpa perpindahan trayek.

\section{Analisis Sistem}

Analisis yang dilakukan terdiri dari 3 hal yaitu keberhasilan sistem, waktu proses, keefektifan hasil trayek. Keberhasilan sistem dinilai dari keberhasilan sistem dalam menemukan rute terpendek dengan pengujian yang dilakukan terhadap 50 kasus yang berbeda. Waktu proses dibedakan menjadi 2 yaitu waktu proses dengan parameter jarak dan waktu proses dengan parameter waktu.

Analisis waktu proses dilakukan dengan pengujian terhadap 50 kasus. Hasil trayek dinilai efektif jika saran trayek yang dihasilkan sistem sesuai dengan kenyataan. Analisis hasil trayek dilakukan dengan pengujian terhadap 25 kasus dengan parameter jarak dan waktu. Oleh karena itu, penulis akan membandingkan hasil trayek tersebut dengan saran trayek yang penulis dapatkan dari pakar. Pakar tersebut adalah pramugara bus Trans Jogja. 
Berikut ini adalah hasil pengujian yang dilakukan pada masing-masing analisis:

1. Berdasarkan pengujian terhadap 50 kasus, sistem mampu menemukan rute terpendek, alternatif rute (jika ada), dan saran trayek.

2. Berdasarkan pengujian terhadap 50 kasus, waktu rata-rata yang diperlukan sistem untuk menemukan rute terpendek dengan parameter jarak adalah 14,88 detik.

3. Berdasarkan pengujian terhadap 50 kasus, waktu rata-rata yang diperlukan sistem untuk menemukan rute terpendek dengan parameter waktu adalah 14,86 detik.

4. Pengujian keefektifan hasil trayek dengan parameter jarak pada 25 kasus, diketahui 3 kasus tidak sesuai dengan kenyataan.

5. Pengujian keefektifan hasil trayek dengan parameter waktu menunjukkan keberhasilan pada 25 kasus.

\section{KESIMPULAN}

Berdasarkan pengujian dan analisa sistem serta memperhatikan keseluruhan proses yang terjadi, maka dapat diperoleh kesimpulan sebagai berikut :

1) Sistem mampu menerapkan algoritma Generate and Test untuk menemukan rute terpendek, rute alternated beserta saran trayek.

2) Sistem mampu menampilkan analisis perhitungan jarak atau waktu beserta jumlah pergantian trayek yang digunakan.

3) Prosentase keberhasilan sistem dalam menemukan rute terpendek dengan algoritma Generate and Test mencapai $100 \%$.

4) Perbedaan rata-rata waktu proses yang dibutuhkan sistem dalam menemukan rute terpendek dengan parameter jarak dan waktu tidak terlalu signifikan yaitu 14,88 detik untuk parameter jarak dan 14,86 detik untuk parameter waktu.

5) Hasil keefektifan hasil trayek yang dihasilkan parameter jarak mencapai $88 \%$ dan keefektifan mencapai $100 \%$ untuk parameter waktu.

\section{Daftar Pustaka}

Kusumadewi, Sri. (2003). Artificial Intelligence: Teknik dan Aplikasinya, Edisi Pertama. Graha Ilmu.

Luger, G,F. (2005). Artificial Intelligence : Structures and Strategies for Complex Problem Solving, $5^{\text {th }}$ Edition. Addison-Wesley. 
Russel, Stuart J and Norvig. (1995). Artificial Intelligence : A Modern Approach. New Jersey : Prentice Hall, Inc.

Shaffer,C.A. (1997). A Practical Introduction to Data Structure and Algorithm Analysis. New Jersey : Prentice Hall, Inc. Wilson, R. dan Watkins, J. (1990). Graphs Theory. Toronto : John Willey \& Sons, Inc. 